\title{
茶園土壤の微生物相に及ぼすスミチオン乳剤の影響
}

\author{
農林水産省 野菜・茶業試験場* \\ 早津雅 仁・徳田進一・中島田 誠 \\ (平成 4 年 6 月 16 日受理)
}

\section{Effect of Fenitrothion Application on Soil Microflora of Tea Field}

\author{
Masahito Hayatsu, Shinichi TOKUdA, Makoto NAKASHIMAdA \\ National Research Institute of Vegetables, Ornamental Plants and Tea
}

\begin{abstract}
The objective of this study was to evaluate the effect of fenitrothion application on soil microflora of tea field. Soil samples from space between hedges in a tea field were treated with 0 , 50,100 and $500 \mathrm{ppm}$ of fenitrothion. The treatments did not show any detectable detrimental effects on the soil microbial population, nitrification, ammonification, soil respiration and urea hydrolyzing activity. The results indicated that the application of fenitrothion was not affect soil microflora in tea field.

Laboratory experiments were made to investigate the enhanced degradation of fenitrothion by prior application of fenitrothion. A clear relation was observed between the frequency of prior application and the rate of fenitrothion degradation. Data obtained from the present study indicated that the repeated application induced enhanced degradation of fenitrothion in tea field soil.
\end{abstract}

\section{1 緒言}

近年静岡県においてナガチャコガネによる 被害面積が急速に拡大し，1989年には被害面 積が15へクタールを越えた1,2)。このため茶 園に和けるナガチャコガネの防除方法が検討 され2), 現在, スミチオン乳剤の土裹潅注に よる防除が指導されている。この方法による と潅注を受けた土镶はスミチオン乳剤にさら される。一方，土壤に存在する多種多様な微 生物は元素循環や浄化作用の中心として機能 し，作物に好適な土裹環境の形成に重要な役 割を果たしているが，これらの政生物は施肥 や農薬などにより影響を受けることが知られ ている。したがってスミチオン乳㶡の土镶潅 注が窒素動態など施肥管理上重要な微生物活 性に影響を及ぼす可能性がある。また近年， 米国を中心に特定の農薬を土裹中に連用する 之, 農薬の分解速度が加速され効果が減退す る現象が報告されたが3,4)，その原因は農薬 分解微生物が集積するためであることが示さ
れた5,6)。

そこで, スミチオン乳剤が茶園土壤の微生 物相と微生物活性に及ぼす影響と連用による スミチオン分解能の変化について検討した。

\section{2 材料及び方法}

\section{1 供試士壌}

供試土壤は野菜茶試（金谷）の茶園のうね 間深さ $0 \sim 10 \mathrm{~cm}$ から採土し, 直ちに $3 \mathrm{~mm}$ のふるいを通した後, ポリエチレン袋に入れ $4^{\circ} \mathrm{C}$ に保存し，適時取り出して使用した。ス ミチオン（フェニトロチオン）の影響を明ら かにするため，一定量の土锿をビーカーに取 り, 市販のスミチオン乳剤 70 を有効成分量 で50，100，500ppm となるように加之，以 下の項目について検討した。

\section{2 微生物の計数}

土裹にスミチオン乳剂を加え 2 週間後に微 生物の計数を行った。系状菌はローズベンガ ル培地, 細菌及び放線菌はェッグアルブミン 培地を用いた。培地 $\mathrm{pH}$ は 4.5 および 7 とし

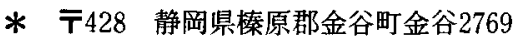


茶園土喪の微生物相に及ぼすスミチオン乳剤の影響

表 1 供試土裹の性質 -1 *

\begin{tabular}{cccccc}
\hline $\begin{array}{c}\mathrm{pH} \\
\left(\mathrm{H}_{2} \mathrm{O}\right)\end{array}$ & $\begin{array}{c}\text { 全炭素 } \\
(\%)\end{array}$ & $\begin{array}{c}\text { 全窒素 } \\
(\%)\end{array}$ & $\begin{array}{c}\text { 有効態リン酸 } \\
\left(\mathrm{P}_{2} \mathrm{O}_{5} \mathrm{mg} / 100 \mathrm{~g} \text { 乾士) }\right.\end{array}$ & $\begin{array}{c}\mathrm{CEC} \\
(\mathrm{meq} / 100 \mathrm{~g} \text { 乾土) }\end{array}$ & $\begin{array}{c}\text { 塩基飽和度 } \\
(\%)\end{array}$ \\
\hline 3.5 & 2.36 & 0.35 & 51.3 & 27.3 & 34.8 \\
\hline
\end{tabular}

* 微生物相への影響に供試した土裹

て希积平板法によった。

2. 3 硝酸化成及びアンモニア化成の測定 硝酸化成はビン培責法により測定した。10g の供試土壤を $100 \mathrm{ml}$ のビーカーに秤取し， スミチオン乳剤及び硫安を含も蒸留水を加 兄アアンモニア態窒素を約 $20 \mathrm{mgN} / 100 \mathrm{~g}$ 乾 土，水分を最大容水量の $60 \%$ に調製し， 25 ${ }^{\circ} \mathrm{C}$ 暗所で培養した。これを 2 連で行い適時取 り出して、アンモニア態窒素と硝酸態窒素を 測定した。

アンモニア化成能は菜種粕を乾土 $100 \mathrm{~g}$ 当 り $100 \mathrm{mgN}$ 加え， $25^{\circ} \mathrm{C}$ で 7 日間培養後，生成 したアンモニア態窒素量を測定した。尿素分 解活性は供試土壇に尿素 $40 \mathrm{mgN} / 100 \mathrm{~g}$ 乾土 を加え，同様に測定した。

2. 4 土堙呼吸の測定

土壤呼吸は石沢らの方法により測定した7)。 ポリエチレンビーカーに $10 \mathrm{~g}$ の供試土壤を 入れ，セルロースパウダー $100 \mathrm{mg} / 100 \mathrm{~g}$ 乾 土とスミチオン乳剤を加えた。これを懸垂式 捕集ビンに吊し, 密栓し $25^{\circ} \mathrm{C}$ 暗所で培養し た。発生した炭酸ガスは捕集ビンの底に入れ た水酸化ナトリウム液に吸収させ，適時，滴 定法により測定した。

\section{5 スミチオン分解能の測定}

茶園のら权間土裹を $1 / 5000$ a ワグネルポ ットに充填し，スミチオン乳剤を回数を变え て散布した。試験区は無散布区, 1 回散布区, 毎月 1 回 6 ケ月散布区の 3 試験区で行った。 また 1 回の散布量はスミチオン乳剤 70 の 2000 倍希釈液を $100 \mathrm{~m} l$ とした。スミチオン 分解能は最初の散布から6ケ月を経過した土 堙を用い,土裹懸濁液培養法により測定した。 分析用の標準スミチオン (和光純薬製, 純度 $98 \%$ 以上）100ppmを含む無機塩培地に供試
土壊を加光 $\mathrm{pH}$ を 7 及び 4.5 に調整した。こ の土钲懸濁液を $25^{\circ} \mathrm{C}$ で振とら培養し，適時 サンプリングした後, 同量のメタノールを加 点 30 分間振とうした。この溶液を $5000 \times \mathrm{g}$ で 30 分間遠心した後，上澄み液中のスミ子 オンを高速液体クロマトグラフィーにより定 量した。分析はODS.C-18, 溶出液》セト二 トリル: 水 $=50: 50$ により行った。

2. 6 化学分析

アンモニア態窒素及び硝酸態窒素はブレム

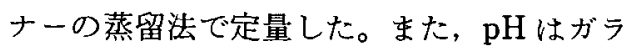
ス電極法により測定した。全炭素はチューリ ン法, 全窒素はケルダール法, 有効態リン酸 はトルオーグ法, 塩基置換容量はセミミクロ ショーレンベルガー法で各々測定した。

\section{3 結果}

3.1スミチオン乳剂が微生物相と微生物活 性に及ぼす影響

スミチオン乳剤が茶園土堙の微生物に及ぼ 寸影響について検討した。供試土壤は赤黄色 土裹で，その主な性質を表 1 に示した。農薬 の铰生物に対する影響を調べるとき，一般に 純品が用いられる。しかし，ナガチャコガネ の防除では，すでKスミチオン乳剂の使用が 指導されている。したがって，現場により近 い条件で検討するため市肘のスミチオン乳剂 を用いた。をた，静岡県の防除基準によれば，

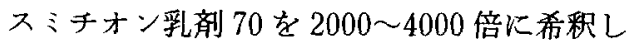
て使用することが示されている†。この場合, 希积液中のスミチオンの有効成分量は 122.5 〜245ppmとなり, 土壤中ではさらに希秎さ れるので濃度の幅が広がる。そこで，供試土 堙のスミチオン乳剤の有効成分量を $0 ， 50$, $100,500 \mathrm{ppm}$ 之幅をもたせ, 各々の濃度に

$\dagger$ 農産物病害虫防除基準（1992）：静岡県農政部農業技術課 
茶業 研 究報告第 76 号 $\left(\begin{array}{llll}1 & 9 & 9 & 2\end{array}\right)$

表 2 スミチオン乳剂が土嫶微生物数に及注す影響*

\begin{tabular}{ccccccc}
\hline $\begin{array}{c}\text { スミチオン濃度 } \\
(\mathrm{ppm})\end{array}$ & \multicolumn{2}{c}{ 細菌 } & \multicolumn{2}{c}{ 放線菌 } & \multicolumn{2}{c}{ 糸状菌 } \\
$(\mathrm{pH} 4.5)$ & $(\mathrm{pH} 7.0)$ & $(\mathrm{pH} 4.5)$ & $(\mathrm{pH} 7.0)$ & $(\mathrm{pH} 4.5)$ & $(\mathrm{pH} 7.0)$ \\
\hline 0 & $5.7 \times 10^{5}$ & $5.9 \times 10^{5}$ & $1.2 \times 10^{5}$ & $1.1 \times 10^{5}$ & $5.0 \times 10^{4}$ & $7.6 \times 10^{4}$ \\
50 & $6.1 \times 10^{5}$ & $6.0 \times 10^{5}$ & $1.3 \times 10^{5}$ & $1.2 \times 10^{5}$ & $3.2 \times 10^{4}$ & $7.9 \times 10^{4}$ \\
100 & $5.2 \times 10^{5}$ & $6.6 \times 10^{5}$ & $1.1 \times 10^{5}$ & $1.1 \times 10^{5}$ & $5.4 \times 10^{4}$ & $9.7 \times 10^{4}$ \\
500 & $4.5 \times 10^{5}$ & $6.6 \times 10^{5}$ & $1.0 \times 10^{5}$ & $1.1 \times 10^{5}$ & $3.2 \times 10^{4}$ & $9.1 \times 10^{4}$ \\
\hline
\end{tabular}

* 乾土 $1 \mathrm{~g}$ 当りの微生物菌数を示した。

おける微生物数之微生物活性について比較検 討した。

茶園土雍は酸性化が進んで括り，土裹 $\mathrm{pH}$ は 4 以下の場合が多 ${ }^{8)}$ ，棲息する微生物の 生育 $\mathrm{pH}$ の範囲も酸性側にあると考えられ る。そこで一般に微生物の計数は pH 7 の培 地で行われるが，pH 4.5 の培地も用いた。 各処理濃度に拈ける微生物数は細菌, 放線菌 及び糸状菌ともスミチオン乳剤による影響は 認められなかった（表 2 ）。

土锖徽生物の機能の弓ち肥培管理上重要な 硝酸化成，アンモニア化成，尿素分解につい てスミチオン乳剤の影響を検討した。硝酸化 成に対する影響は，供試土壤に硫安を加え硝 酸態窒素の生成量を比較した（図 1 )。各測 定日の硝酸態窒素生成量から，スミチオン乳 阂は硝酸化成能に影響を及ぼさないことが示 された。アンモニア化成能は菜種粕分解によ り生成したアンモニア態窒素とこれが硝酸化 成を受けて生成した硝酸態窑素の合計で示し た（表 3 )。処理濃度の差によりアンモニア 化成能に違いが認められないことから，アン モニア化成はスミチオン乳剤の影響を受けな いことが示された。尿素分解能もアンモニア 化成能と同様に表した(表 3 )。無処理と500 ppm 処理での尿素分解能はほぼ同等である ことから，尿素分解能はスミチオン乳剂の影 響を㾏とんど受けないことが示されだ。

土嚊は炭酸がスを発生するが，これを土壤 呼吸といい，䗎生物の活性を知る指標になる。 また，茶園には稲菜などの多量の有機物が施 用されるが，これらの主成分はセルロースで ある。そこで，セルロースを加えたときの土 壤呼吸に及ばすスミチオン乳剤の影響につい
表 3 スミチオン乳剤がアンモニア化成及び尿素 分解に及注す影響

\begin{tabular}{ccc}
\hline $\begin{array}{c}\text { スミホン濃度 } \\
(\mathrm{ppm})\end{array}$ & $\begin{array}{c}\text { アンモニフ化成能 } \\
\left(\mathrm{NH}_{4}^{+}-\mathrm{Nmg} / 100 \mathrm{~g}\right. \\
\text { 乾土/7日 })\end{array}$ & $\begin{array}{c}\text { 尿菜分解能 } \\
\left(\mathrm{NH}_{4}^{+}-\mathrm{Nmg} /\right. \\
100 \mathrm{~g} \text { 乾土/7日 })\end{array}$ \\
\hline 0 & 13.7 & 23.7 \\
50 & 12.5 & 19.2 \\
100 & 12.3 & 20.3 \\
500 & 12.9 & 23.5 \\
\hline
\end{tabular}

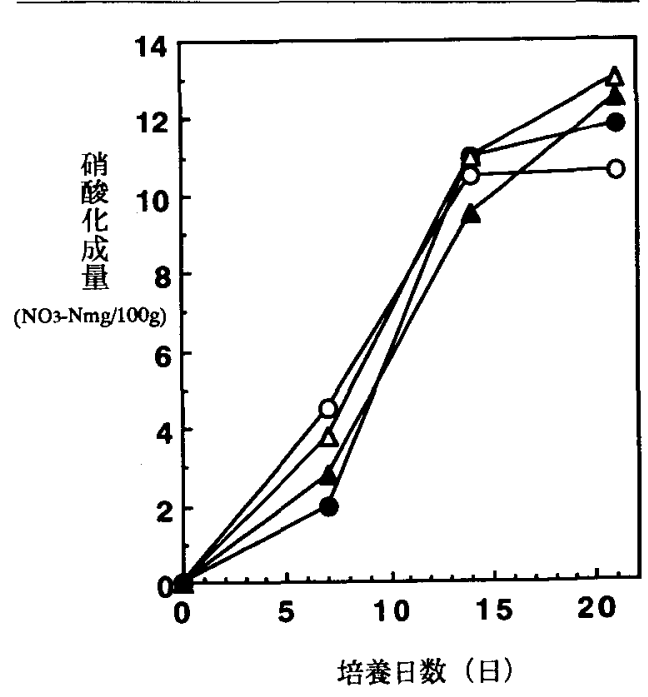

図1スミチオンが硝酸化成に及注す影響 スミチオン濃度 : $0 ， 0 \mathrm{ppm} \quad \bullet, 50 \mathrm{ppm}$ $\triangle, 100 \mathrm{ppm} \quad \boldsymbol{\Delta}, 500 \mathrm{ppm}$

て検討した。培養開始後 33 日目まで各処理 土裹とも炭酸ガスは注ぼ同様の割合で直線的 に増加したことから，スミチオン乳剤はセル ロース分解による土攐呼吸に影響を及湆さな いことが示された（図 2)。

3. 2 スミチオンの分解に及注す影響 スミチオン乳剤の散布回数の異なる土镶に 


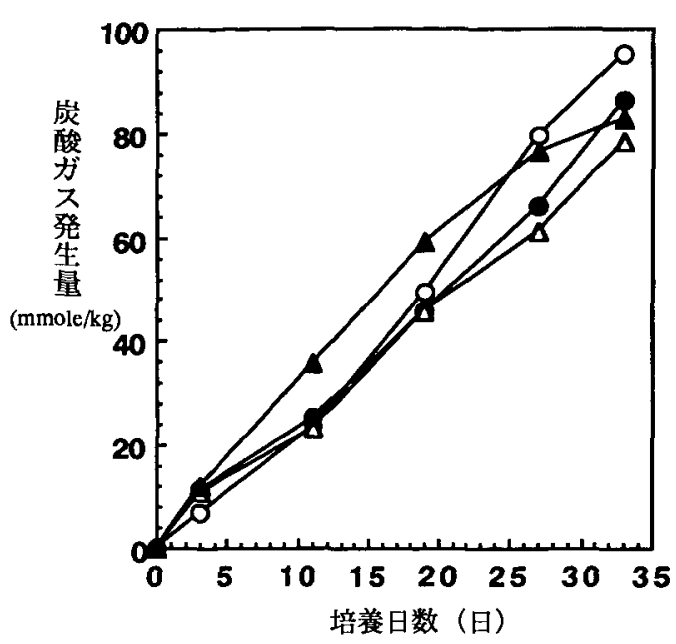

図 2 スミチオンが土壤乎吸に及ぼす影響 スミチオン濃度：○， $0 \mathrm{ppm} \quad \bullet ， 50 \mathrm{ppm}$ $\triangle, 100 \mathrm{ppm} \quad \Delta, 500 \mathrm{ppm}$

ついて，土壤懸濁液培養法によりスミチオン 分解能を調べた。供試土壤の性質を表4に示 した。土壌緊濁液の $\mathrm{pH}$ は 4.5 と 7 の 2 種類 で行い, 培養開始後 12 日目のスミチオン残 存量を示した（表 5 ）。pH 4.5 の培地では無 処理区で $72.8 \%$, 散布 1 回区で $81.7 \%$ のス ミチオンが残存していた。また, 散布 6 回区 の残存量は $41.2 \%$ で他の処理区に比べ分解 能が高かった。pH 7 の培地では無処理区に 対し散布 1 回区の分解能が若干高く, 散布 6 回区では $93.7 \%$ が分解され最も高い分解能 を示した。これらの結果からスミチオン乳剤 を短期間に連続散布するとスミチオンの分解 速度が加速され，殺虫効果を低下させる可能 性が示された。

\section{4 考察}

ナガチャコガネによる被害は幼虫が根部を 食害することにより起こり，食害が激しいと 一番茶芽の生育が悪く収量が激減する。この 幼虫は地表から地下数 $10 \mathrm{~cm}$ 範囲に棲息す るため9，防除には薬剤の土堙潅注が行われ る。静岡県の場合, $70 \%$ スミチオン乳剂の 2000〜 4000 倍液を $5 \mathrm{l} / \mathrm{m}^{2}$ 散布するよら指導 しており，被害が予測される場所だけに土壌
潅注が行われる。1 $\mathrm{m}^{2}$ 当り $5 \mathrm{l}$ の潅注が行れ ると，その部分はスミチオンにさらされる。 実際に使用されるスミチオン乳剤の濃度は 122.5 245ppmであり，これらは土堙中で さらに希积されると考兄られる。本報告では 供試土壤のスミチオン乳剂の濃度を有效成分 量で 0，50，100，500ppmとし，実際より も高い、濃度の影響まで調べた。

微生物数, アンモ二ア化成能, 尿素分解能 および土壤呼吸はスミチオン乳剤の影響を汪 とんど受けなかった。これらの作用は複数の 種類の微生物によるため，農薬などの化学物 質の影響を受けにくい10)。一方，硝酸化成は アンモニア酸化菌之亜硝酸酸化菌の 2 種類の 細菌による作用である。このような特定の微 生物による作用は土壌環境の变化や農薬によ り影響を受けや寸い10)。しかし，図1に示す ようにスミチオンの影響により硝酸化成能の 阻害は認められなかった。以上の結果から， 防除基準の範囲内においてスミチオン乳剤は 茶園土壤の微生物に影響を及ぼさないと考え られた。

緒論で述べたように米国に扮いて，特定の 農薬を連用することにより，その農薬を分解 する微生物が増加するため，土㙵中に利ける 農薬分解能が高まり，農薬の効力が失われる ことが報告されている3４）。最初に分解促進 による効果の低下が認められたのは，トウモ ロコシ栽培で土堙害虫の防除に使われるカー パメイト系殺虫剤カルボフランで3)，分解を 促進する分解菌も分離されている11。また， これ以外の農薬でも分解促進が起こることが 報告されている12)。表 5 に示すよらにスミチ オンも連用により分解の加速が起こることが 示された。しかし, 明らかに分解速度の上年 が認められたのは月 1 回の散布を 6 回継続し た場合であり，実際にはこのように高い頻度 で散布されることはない。したがって，使用 頻度が低ければ分解の促進による効力の低下 は起こりにくいと考光られる。

茶園土镶は強酸性化しているため分解能の 測定はpH 7 と 4.5 の培地を用いたが， pH 7 の方が 4.5 に比べ分解速度が早かった。こ 


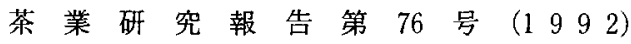

表 4 供試土堙の性質 -2 *

\begin{tabular}{cccccc}
\hline $\begin{array}{c}\mathrm{pH} \\
\left(\mathrm{H}_{2} \mathrm{O}\right)\end{array}$ & $\begin{array}{c}\text { 全炭素 } \\
(\%)\end{array}$ & $\begin{array}{c}\text { 全窒素 } \\
(\%)\end{array}$ & $\begin{array}{c}\text { 有効態リン酸 } \\
\left(\mathrm{P}_{2} \mathrm{O}_{5} \mathrm{mg} / 100 \mathrm{~g} \text { 榦土) }\right.\end{array}$ & $\begin{array}{c}\mathrm{CEC} \\
(\text { meq. } / 100 \mathrm{~g} \text { 乾土) }\end{array}$ & $\begin{array}{c}\text { 塩基飽和度 } \\
(\%)\end{array}$ \\
\hline 3.9 & 2.19 & 0.49 & 27.8 & 48.8 & 38.3 \\
\hline
\end{tabular}

* スミチオン分解への影響に供試した土壤

表 5 スミチォン乳剤の散布回数が土壌中のスミチオンの分解能に及ぼす影響

\begin{tabular}{ccc}
$\begin{array}{c}\text { スミチオン乳剂散布回数 } \\
(\text { 回 } / 6 \text { ケ月) }\end{array}$ & $\begin{array}{c}\text { 培養 } 12 \text { 日後のスミチオン残存量 }(\%) \\
\text { 培地pH4.5 }\end{array}$ & $\begin{array}{c}\text { 培地pH } 7.0 \\
\text { 散布ナシ }\end{array}$ \\
1 回散布 & 72.8 & 64.1 \\
6 回散布 & 81.7 & 52.4 \\
\hline
\end{tabular}

れは分解菌の生育の至適 $\mathrm{pH}$ が中性付近にあ ることを示している。供試土壌の $\mathrm{pH}$ は 3.9 だが微視的な土垶 $\mathrm{pH}$ の分布には，かなりば らつきがあると考えられて牤り，分解菌は土 裹中の比較的 $\mathrm{pH}$ 高い場所に棲息している と考えられる。

農薬の効力の持続といら点では, 農薬分解 菌の活性は弱い汪ど良いかもしれない。しか し，農薬分解菌が土壤に和ける埩化作用の中 心として機能しているために土㙋污染や残留 は起こらない。したっがて，土壤潅注による 防除等では散布回数による農薬分解能の变動 を予測する技術の開発が望まれるが，このた めには農薬分解菌についてさらに研究を進め る必要がある。

\section{5 摘要}

茶園上壤の微生物に及ぼすスミチオンの影 響について検討した。茶園らね間から採取し

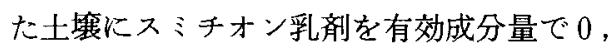
50，100，500ppmkなるよらに加光，その 影響を調べた。いずれのスミチオン濃度に尔 いても, 微生物数, 硝酸化成能, アンモニア 化成能，尿素分解能及び土壤呼吸の阻害は認 められなかった。このことから防除基準の範 囲内（スミチオン乳片70の 2000 4000 倍希 釈液を $1 \mathrm{~m}^{2}$ 当り $5 l$ 散布) に拉けるスミチ才 ン乳剤の使用は茶園土壌の微生物に影響を与 えないと考えられた。
スミチオンの連用による分解能の促進現象 について奏験室レベルで検討した。スミチオ ソの継続的な散布により土壌のスミチオン分 解能が著しく高くなった。れらの結果から, 茶園土壌に抏いても継続的な散布が行われる と, スミチオン分解能の加速が起こりうるこ とが示された。したがって, 防除効果の面か らは土壌潅中の乱用は避ける必要がある。

\section{6 引用 文 献}

1）大秦司誠（1980）：チャの新害虫ナガチ ヤコガネ，茶研報 (講要), No51，88

2）静岡県農政部農業技術課（1989）：ナガ チャコガネの生態と防除, あたらしい農 業技術, No181，1１5

3) Felsot, A. S., Wilson, J. G., Kuhlman, D. E. and K. L. Steffey. (1982) : Rapid dissipation of carbofuran as a limiting factor in corn rootworm (Coleoptera : Chrysomelidae) control in fields with histories of continuous carbofuran use. J. Econ. Entomol. 75, 1098-1103.

4) Obrigawitch, T., Roeth, F.W., Martin, A. R. and R. G. JR. WILson. (1982) : Addition of R-33865 to EPTC for extended herbicide activity. Weed Sci. 30, 417 -422 .

5) Tam, A.C., BehKi, R. M. and Khan. S. U. (1987) : Isolation and characteriza 
茶園土壤の微生物相に及ぼすスミチオン乳剤の影響

tion of an $s$-ethyl- $N, N$-dipropylthiocarbamate degrading Arthrobacter strain and evidence for plasmid associated $s$-ethyl- $N, \quad N$-dipropylthiocarbamate degradation. Appl. Environ. Microbiol. 53, 1088-1093.

6) Felsot, A., Maddox, J. V. and W. Bruce. (1981) : Enhanced microbial degradation of carbofuran in soils with histories of Furadan use. Bull. Environ. Contam. Toxicol. 26, 781-788.

7）营原和夫：土壤標準分析・測定法, 土裹 呼吸, p. $270 \sim 280$, 博友社, 東京 (1986)

8）渡部育夫・池ヶ谷賢次郎（1987）：多肥 栽培下に扣ける超強酸性茶園土壤の化学
性, 茶研報, No65，65～72

9）刑部勝・小泊重洋（1984）：チャを加害 するナガチャコガネの生態, 茶技研, No66, 15 21

10）佐藤匡 : 土の微生物，農薬と土㖶の微生 物, p.389 433, 博友社, 東京 (1981)

11) Karns, J. S., Mulbry, W. W., Nelson, J. O. and P. C. KeARNEY, (1986): Metabolism of carbofuran by a pure bacterial culture. Pestic. Biochem. Physiol. 25, 211-217.

12）山田忠男（1990）：農薬の微生物分解の 高まりとその制御，植物防疫，44 (2)，62 $\sim 66$ 